\title{
The Sea as Life Support for Bugis People in Colonial Period
}

\author{
Alamsyah $^{1^{*}}$, Mualimin Mualimin ${ }^{2}$, and Agustinus Supriyono ${ }^{1}$ \\ ${ }^{I}$ Lecturer of History Department, Faculty of Humanities, Diponegoro University, Semarang - \\ Indonesia \\ ${ }^{2}$ Lecturer of English Department, Faculty of Humanities, Diponegoro University, Semarang - \\ Indonesia
}

\begin{abstract}
This article wanted to describe how the sea became a pillar in Bugis people's life. The purpose of the study was to explain analytically concerning the Bugis people's livelihoods related to the sea, such as being fishermen, carrying out trading activities, and piracy. The method used was the historical method which included heuristics, criticism, interpretation, and historiography. The results indicated that Bugis people from then until the colonial period mainly depended on the marine environment. They lived in coastal areas that were close to sea life and depended on their life to the sea. Some of Bugis livelihoods during the colonial period were being fishermen, trading activities, and becoming pirates. Some of the fishing products were consumed by themselves, and the rest were sold. Activities in the commercial sector were carried out through trading activities. They sailed and traded on an international and inter-insular scale. Some other Bugis people depended their lives on piracy. They pirated in coastal areas and in the archipelago ocean. This study concluded that Bugis people's life could not be separated from a marine environment. It was through the sea that during the colonial period, they could exist, survive, and develop. For Bugis people, marine environment was seen as a pillar of the community's economy.
\end{abstract}

\section{Introduction}

The Buginese are known as sailors who are recognized for their toughness in the archipelago. They explored almost all waters in the archipelago and even reached Australia before Westerners came to Australia [1]. When the Portuguese annexed Malacca and Maluku around the 16th century, which was followed by the VOC and the Dutch East Indies in the 17th to the 20th century, of course, they disturbed the tribes whose lives depending on the sea, including the Buginese. Therefore, there was

*Corresponding Author: alamsyah.fib@live.undip.ac.id 
resistance against colonialism in various islands, including the Buginese resistance in Sulawesi. The form of resistance was carried out by pirating Dutch merchant ships. For the Bugis people, the sea is something very valuable because they depend on life and maritime culture. Maritime culture had become part of the life journey of the Buginese long before Westerners came to the archipelago. With this maritime culture, the Buginese, in all aspects of their life, make the most of all things related to the sea [2].

Maritime culture, for the Bugis people, is a culture that is deeply rooted. They manage and utilize the marine environment as a source of livelihood. In addition, they also have a traditional custom system that is patterned in their culture. One of the essences of this belief system is that nature inhabited by humans (including land and sea, and air) is controlled and governed by a supernatural force. This supernatural power greatly determines the success and failure of a person in every activity, especially activities at sea. Therefore, everyone must maintain a harmonious relationship with these supernatural powers through various forms of ceremonial activities and certain behaviours that have been determined by their cultural patterns [3].

The Bugis people regard the sea as life support and depend on the sea. The Buginese had several occupations related to the sea during the colonial period. Bugis people used the sea to meet their daily needs, and they looked for fish in the sea to be consumed or sold. They sailed to trade to various islands in the archipelago. They carried out piracy to obtain goods or people (slaves), which were then sold and bartered. Thus, the Buginese can be said to have a job that is closely related to the sea. The sea could be seen as the main support for the life of the Buginese during the colonial period.

On this basis, this article will reconstruct the life of the Buginese in the Colonial Age of the Sea, which was supported by the sea.

\section{Method}

The writing of this article uses a historical method consisting of heuristics, criticism, interpretation, and historiography [4]. Heuristics is a process of searching for primary and secondary sources [5]. Primary sources are obtained from the Jakarta National Archives in the form of government reports during the colonial period or photographs of Buginese ships used for fishing. Secondary sources are obtained from relevant works in the form of books, journals, and other literature. Secondary sources are obtained from libraries, private collections, and online. The available sources are then criticized and interpreted. The results of the above analysis are reconstructed into an article about the sea as the life support for the Buginese in the colonial period. 


\section{Discussion}

\subsection{Bugis people as fishermen}

The Buginese fishing community is the heir to a maritime culture from Polynesian Malay who has had special expertise as boatbuilders since 2000 years ago. Buginese fishermen have the idea of the sea that the fish in the sea are abundant and will not run out as long as the leaves of the trees on the land are not used up. No particular person owns the vast sea with all in it. The sea is seen as being created by God for human use with prayer and endeavour. With any exploitation technology, it will not consume the contents of the sea, except only reduce the population, try and take advantage of this grace or blessing or gift from the Creator. Buginese fishermen do not fish for small fish by the sea but go out to sea to catch big fish so that their business can thrive [6]. Buginese fishermen also have an idea about the wide sea, but not all parts are accessible. This view grew from the experience of Buginese fishermen in interacting with marine resource management institutions, for example, individual, communal ownership and state control [7].

Buginese fishermen rely on the senses of pakkita (sight), parengkalinga (hearing), paremmau (smell), panedWng (premonition), and tentuang (belief) to pick up on signs or signals of danger at sea. Buginese fishermen have knowledge of the seasons and dangers in the sea based on knowledge of astronomy according to the layout of the stars [8].

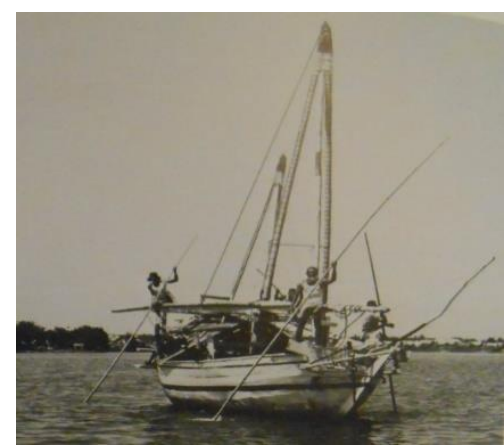

Fig. 1. The Pataroni fishing boat, used by the Sulawesi people (Buginese).

Source: Clifford W. Hawkins, Praus of Indonesia, London: Nautical Books, 1982, p. 48

Fishermen in South Sulawesi, including Buginese fishermen, knew about 40 types of sea cucumbers during the colonial period. The sea cucumbers that have been known include the koro type of sea cucumber, peel off, tai kongkong, batu, kassi, pineapple, and view fishermen also know various types of shells such as pearls, tola, match stone, seven eyes, and clams. They know several types of fish that have high economic value, such as reef fish, especially the species of sunu (red snapper), grouper, faccukang or fangkoe (napoleon), sharks (their fins are taken), and shrimp. Fishermen are also familiar with several pelagic fish, such as kites, skipjack or tuna, and banjara 'or sarisi (sardines) which are marine commodities that sell well in local and regional markets [9].

Buginese fishermen generally come from the coastal villages of South Sulawesi and the surrounding islands stretching from Luwuk, Wajo, Bone, Sinjai, Bulukumba 
in the east (facing Bone Bay), Bantaeng, Jenneponto, Takalar, Gowa, Kota Makassar, Maros, Pangkep (Pangkajenne Islands), Barru, Parepare, and Pinrang in the western part of the island (opposite the Makassar Strait) [10]. The Buginese were widely known as fishermen or fish hunters in the Malacca Strait during the Sriwijaya era. The Strait of Malacca is a gathering place for fish, thus attracting the presence of the Buginese [11]. They operate in various fishing grounds in the eastern and southern regions of the archipelago to the north and west coasts of Australia [12].

Some evidence that they work as fishermen can be shown from the reports of the Dutch colonial government in the 19th century. Dutch records mention that the Buginese looked for fish in the sea using small boats. Most of the Bugis people looked for fish around their homes, especially those using small boats [13].

\subsection{The Buginese as Sailors and Traders}

The Western nation exercised strict control and implemented various rules that restricted, prohibited shipping and trading activities in the controlled archipelago. Western nations managed to paralyze the power of shipping and commerce in the community; even some merchant groups managed to resist or at least survive in the midst of Western domination. Under such conditions, the Buginese continued to trade during the colonial period despite facing threats from the West [14].

They are one of the ethnic groups in the archipelago that have an important role in marine trade activities [15]. It can be said, they are very dependent on the sea or waters as a medium to seek sustenance. Most of the Bugis people act as intermediary traders. Buginese traders have a function as distribution traders who sell and distribute public consumption goods. Buginese traders also function as collectables in charge of collecting agricultural products and then selling them to consumers [16].

Bugis people who persevered in maritime trade during the colonial period did earn not only income but also the morality of business that was passed on by their ancestors. The morality of business emphasizes that they do not like people who are idle, lazy, have no effort, spend their time in vain, and are useless. Buginese traders also had to adhere to some basic rules. First, they must prioritize honesty because honesty can lead to trust. Second, they have to do social or human relations because it will make it easier to develop a business. Third, they use science because it will improve management. In trading, the Buginese were always on guard against the kings, the strongmen, the rich, and their acquaintances. However, they have a belief that "sustenance must be sought" [17].

Some evidence suggests that Buginese traders continued to trade during the colonial period. In the 16th century, Buginese traders played an important role in marine trade in the archipelago after the fall of Malacca to the Portuguese. Buginese traders played an important role in the conflict between the major powers in Malacca, especially between the Portuguese, Dutch and Malay kings [18]. In the 17th century, Buginese traders were already trading in Papua. They become distributors of ceramics, iron tools and cloth for the Papuan people. Buginese traders in trading and shipping to Papua used the route along the Makassar Strait to the north, then sailed eastward into North Sulawesi and continued to Ternate until they reached Papua. These Buginese traders were involved in shipping and trading networks to Papua until the 19 th century [19]. 
In the 19th century, Buginese traders sold their goods in Tidore, Bacan, Seram, and the hinterland of Halmahera. They brought opium, ammunition, and weapons at low prices from Singapore [20]. During this time, Buginese traders had also traded in Afdeeling Jailolo and Sahoe, an area located in West Halmahera. They traded and brought in European-made goods such as cloth, ironwork, porcelain and pottery. They also bought local commodities such as tripang (shellfish), cocoa, coffee, copra and swallow's nest [21]. In the century, Buginese traders also made commercial voyages to the Ternate region. They were actively trading, and some of them have settled in Ternate. Merchandise brought was in the form of household necessities, such as pottery, iron, cloth, and foodstuffs. These commodities were then exchanged (bartered) with local products such as nutmeg, copra, resin, shellfish, pearls, shark fins, and turtle shells. Buginese traders who came to Ternate were interested because Ternate port was a free port [22].

Buginese traders did not only come to trade but also to settle in Ternate. In Ternate, they formed an active indigenous trade diaspora. These traders were intermediate traders who were advanced at that time. The Buginese merchant community formed a trading network by placing a person in the villages where seafood commodities originated. This community came under pressure after the Dutch East Indies government came to power in Ternate. However, Buginese traders were still able to continue their trade in Nusantara waters [23].

In the 19th century, Dutch records noted that many Buginese sailors and traders were active in shipping and trading in the Indonesian seas. Buginese traders usually sailed using Padewakang, Soppe, and Padukan boats. Buginese boats carried loads of corn, rice and cloth. Buginese traders traded in the areas of Gorontalo, Ternate, Buton, Luwu, Java, and West Kalimantan [24].

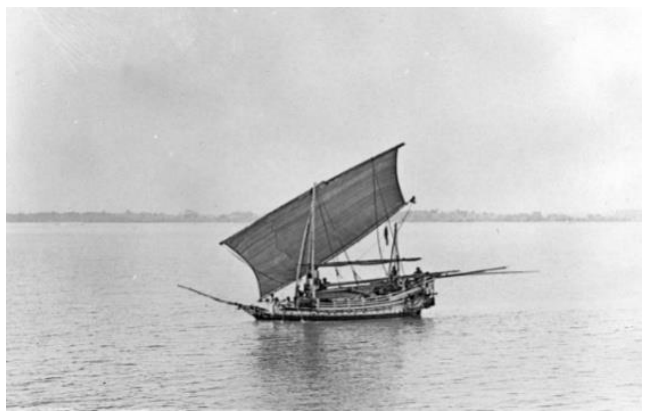

Fig. 2. Padewakang boat.

Source: Tropenmuseum, Collectie Stichting Nationaal Museum van Wereldculturen 


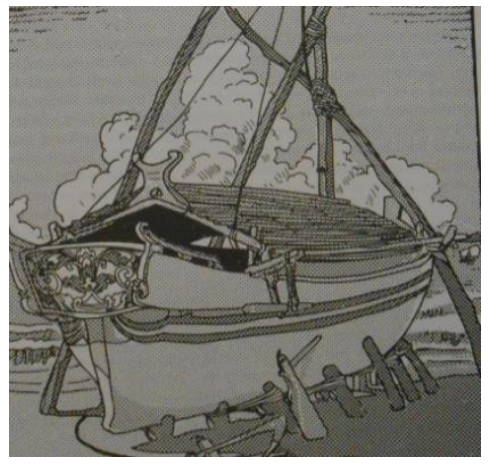

Fig. 3. Painting of Soppe's boat.

Source: Adrian Horridge, The Prahu, Traditional Sailing Boat of Indonesia, Singapore: Oxford University Press, 1985, p. 61

In the 20th century, Buginese traders intensively traded to Kendari (Kolaka), Southeast Sulawesi. These Bugis traders came from the Bone, Luwu, Wajo, and eastern districts of South Sulawesi [25]. They also carried out trading activities as far as Sulu, Banjarmasin, Palembang, Johor, Pahang and Aceh. Buginese traders stopped by at various ports on the east coast of Kalimantan, such as Kutai Pasir and Samarinda. They also traded in Kaili, Bone, Gorontalo, Manado and Kema. The port which Buginese traders had visited would be used as a trading colony [26]. According to Pelras, the Buginese are respected inter-island traders, and their influence is strong enough to bring about the phenomenon of the emergence of the Buginese diaspora. They then formed Buginese settlements, which are often found in various parts of the archipelago [27].

\subsection{Bugis people as pirates}

The Buginese, as respected seafarers in the archipelago, is often accused of being pirates and associated with pirate activities during the colonial period. This view is inseparable from the large number of Bugis people who were involved in the slave trade. Most of the Buginese traders did sell slaves to various regions in the archipelago. In the 17 th to 19 th centuries, slaves were a very profitable trading commodity, so that Buginese traders were actively involved in the slave trade in the archipelago [28]. Several sources said that due to some conditions, the Buginese were involved in piracy activities. The existence of the Buginese as pirates was triggered by the presence of the Western Nation in the archipelago, which was seen as disturbing the economic, social and political stability of the Bugis people. The Dutch then dominated the waters of the archipelago and narrowed the space for people to make a living [29]. We know that the Bugis people, before the arrival of the Western nation, relied heavily on the sea to meet their daily needs. When their economic resources were disrupted, they chose shortcuts to make a living by pirates in the middle of the sea and the coast.

The involvement of the Buginese in pirating activity was carried out on the north and east coast of Sulawesi. In carrying out the action, they had a clever strategy and way of working. This was done by establishing bases that are strategically located between major ports or near the transit of ships along with their operational areas. 
Among the bases created are in Donggala, which functions to supervise the activities of ships in Palu Bay [30]. The bases in Kalangkangan are used to oversee the ports of Tolitoli and Kwandang. Pangkalan Kalangkangan is also used to intercept ships carrying merchandise from Gorontalo to Manado or vice versa. Each base has a leader. They form networks that help each other when facing enemies [31].

In the 17th century, the Dutch considered the existence of Buginese pirates interfered with commercial shipping in the eastern archipelago. Buginese pirates often conspired with the pirates of Makassar, Mandar, Mindanao, and Tobelo to carry out piracy activities in Indonesian waters. In the 17th to 18th centuries, Buginese pirates had their bases on an island near Samarinda. There were times when they also supported certain sultans in Kalimantan in internal conflicts within the palace. When the supported sultans won the victory, they got a place of honour, or at least protected by the ruler and were left to hide in Kalimantan from the pursuit of Dutch troops [32]. In the 18th century, a Buginese pirate named Sarena and a hundred of his men landed in the Mabampa area (Gorontalo). This group carried out various acts of violence in the coastal area. They captured the Gorontalo people to become slaves and sold them to Buton [33]. This Buginese pirate group carried out piracy operations around the Malacca Strait and the east coast of Sumatra. Generally, they came from bases in North Kalimantan, which are centred in Marudu Bay and Tempasuk. Pirates appeared in Riau waters as a form of resistance against the Dutch who controlled the tin trade, even though the tin trade was already controlled by the Buginese. With the establishment of a base in the Reteh area, which was located between the mouths of the Jambi and Indragiri rivers, the position of Buginese pirates was getting stronger in the waters of Riau and the east coast of Sumatra [34]. In the 19th century, according to the Singapore Free Press, it was stated that Buginese pirates had committed acts of piracy on Bawean Island. They were also involved in piracy in Central Sulawesi (Kaili), East and Southeast Kalimantan (Pegatan), and the Singapore Strait [35]. At this time, Buginese pirates had bases on Komodo and Sape Islands in East Sumbawa. These bases were used to attack villages on the north coast of Sumba and to capture villagers into slavery [36].

\section{Conclusion}

There is a very close relationship between the Buginese and the sea, and even the sea, which supports life, has an important role for the Buginese. With the marine environment, the Bugis people depend on their livelihoods as fishermen, namely fishing or shellfish in various parts of the archipelago. Some of them become crossisland traders who stop over from one port to another. They sailed and traded to the ports of Sulawesi, Maluku, Papua, Nusa Tenggara, Java, Kalimantan, Sumatra, the Malay Peninsula and the Southern Philippines. When the waters of the archipelago were mostly controlled by colonialists, they remained as fishermen and traders to make ends meet. Apart from that, some of the other Bugis people also became pirates. This was done when the colonial government tightly controlled shipping and trading activities. This condition made the Bugis people survive by committing piracy in the waters of Sulawesi, Nusa Tenggara, Java and Kalimantan. The ones pirated were Dutch merchant ships and indigenous merchant ships. From the above description, it shows that the majority of the Bugis people live supported by the sea for activities as fishermen, traders and pirates. 
The research is funded by Ministry of Research and Technology / National Research and Innovation Agency of Republic of Indonesia in 2021 budget year.

\section{References}

1. C. Pelras, Buginese Man, (2006)

2. Octavian, Maritime Language and Culture: Identity and National Culture Enrichment, PUSTAKA, 19(1), (2019)

3. H. Naping, Sea, Humans, and Culture, (2017)

4. G. Garraghan, A Guide to Historical Method, (1947)

5. N. Herlina, Historical Methods, (2008)

6. N. Indar, Lampe, Traditional Systems as Institutions in the Management of Resource Utilization in Coastal Areas, (2002)

7. Yunandar. Maritime Culture and Fishermen Traditions in Indonesia, Sabda, (2004)

8. Yunandar. Maritime Culture and Fishermen Traditions in Indonesia, Sabda, (2004)

9. Yunandar. Maritime Culture and Fishermen Traditions in Indonesia, Sabda, (2004)

10. M. Lampe, The Role of Sailors in the Reproduction of the Archipelago's Maritime Geo-Bio-Socio-Cultural Unit: Learning from Buginese-Makassar Rambling Fishermen in South Sulawesi, Journal of Society \& Culture, 18(2), (2016)

11. Bandung, A. B. Takko, Buginese Culture and Its Spread in the Perspective of Cultural Anthropology, Cultural Lens, 15(1), (2020)

12. M. Lampe, The Role of Sailors in the Reproduction of the Archipelago's Maritime Geo-Bio-Socio-Cultural Unit: Learning from Bugis-Makassar Rambling Fishermen in South Sulawesi, Journal of Society \& Culture, 18(2), (2016)

13. Berigten Omtrent den Zeeroof in den Nederlandschen-Archipel over 1858, in Tijdschrift voor Indische Taal-, Landen Volkenkunde, published TBG, 8, 1858

14. S. T. Sulistiyono, Concept of State Borders in the Archipelago: Historical Studies, (2009)

15. H. W. Dick, Indonesian Shipping Industry: Competition and Regulation, (1987)

16. R. Hasim, From Monopoly to Free Port: Trading Activities in the Residency of Ternate 1854-1930, Sasdaya, 3(2), (2019)

17. Bandung, A. B. Takko, Buginese Culture and Its Spread in the Perspective of Cultural Anthropology, Cultural Lens, 15(1), (2020)

18. Bandung, A. B. Takko, Buginese Culture and Its Spread in the Perspective of Cultural Anthropology, Cultural Lens, 15(1), (2020)

19. M. I. Mahmud, Shipping and Trade in the XVII-XIX Century of Bugis-Makassar, Papua, 5(1), (2013)

20. R. Hasim, From Monopoly to Free Port: Trading Activities in the Residency of Ternate 1854-1930, Sasdaya, 3(2), (2019) 
21. A. B. Lapian, In the introduction to Memoie van Overgaua J.H. Tobias (1857) Memorie van Overgave C. Bosscher Resident of Temate (1859), (1980)

22. R. Hasim, From Monopoly to Free Port: Trading Activities in the Residency of Ternate 1854-1930, Sasdaya, 3(2), (2019)

23. R. Hasim, From Monopoly to Free Port: Trading Activities in the Residency of Ternate 1854-1930, Sasdaya, 3(2), (2019)

24. Berigten Omtrent den Zeeroof in den Nederlandschen-Archipel over 1858, in Tijdschrift voor Indische Taal-, Landen Volkenkunde, published TBG, 8, (1858)

25. N. Nur, B. Purwanto, D. Suryo, Trade and Economy in South Sulawesi, in the 1900s to the 1930s, Journal of Cultural Studies, 4(1), (2016)

26. Hasanudin, Trafficking of Bugis People in the Tomini Bay Area during the Dutch Colonial Period, Patrawidya, 18(2), (2017)

27. C. Pelras, Buginese Man, (2006)

28. C. Pelras, Buginese Man, (2006)

29. C. Pelras, Buginese Man, (2006)

30. Omschrijving Rapport over krijgsverrichtingen tegen zeerovers bij N.K. Celebes in 1822 Rubriek Zeeroverijen, National Archief Den Haag (NAH), (462)

31. Hasanudin, Trafficking of Bugis People in the Tomini Bay Area during the Dutch Colonial Period, Patrawidya, 18(2), (2017)

32. Alamsyah, A. Supriyono, Mualimin, Immigration, Diaspora, and Buginese Pirates, (2020)

33. Hasanudin, Trafficking of Bugis People in the Tomini Bay Area during the Dutch Colonial Period, Patrawidya, 18(2), (2017)

34. A. B. Lapian, Sea People, Pirates, Sea Kings: History of the XIX Century Celebes Sea Region, (2009)

35. C. Pelras, Buginese Man, (2006)

36. Alamsyah, A. Supriyono, Mualimin, Immigration, Diaspora, and Buginese Pirates, (2020) 